\title{
Soil mesofauna in consolidated land use systems: how management affects soil and litter
}

\section{invertebrates}

\author{
Maurício Rumenos Guidetti Zagatto ${ }^{*} \oplus^{\circ}$, Luiz Antônio Zanão Júnior ${ }^{2} \odot$, Arthur Prudêncio de Araújo Pereira ${ }^{1}$, German Estrada-Bonilla ${ }^{3}$, \\ Elke Jurandy Bran Nogueira Cardoso ${ }^{10}$
}

\author{
UUniversidade de São Paulo/ESALQ - Depto. de Ciência do \\ Solo, Av. Pádua Dias, 11 - 13418-900 - Piracicaba, SP - \\ Brasil. \\ 2Instituto Agronômico do Paraná - Depto. de Solos, Rod. \\ PRT 163, km 188 - 85825-000 - Santa Tereza do Oeste, \\ PR - Brasil. \\ ${ }^{3}$ Corporación Colombiana de Investigación Agropecuaria/ \\ AGROSAVIA - Tibaitatá- 250047 - Mosquera - Colombia. \\ ${ }^{*}$ Corresponding author <mauriciozagatto@usp.br>
}

Edited by: Fernando Dini Andreote

Received April 22, 2017

Accepted November 08, 2017
ABSTRACT: Soil mesofauna consists of small invertebrates that live in the soil or litter and are sensitive to climatic conditions, management systems, plant cover and physical or chemical soil attributes. These organisms are active in the cycling of nutrients, since they fragment the organic matter hereby accelerating microbial decomposition. The aim of this study was to evaluate the invertebrate community in no-tillage, conventional tillage, minimum tillage and secondary forest in regeneration to determine the relationship of mesofauna to litter, soil attributes, management and seasonality. Therefore, ten soil samples in each system and eight litter samples in no-tillage and the forest were taken over four seasons. These samples remained in Berlese extractors for seven days for quantification and identification of mesofauna. For each fauna sample, soil samples were collected for chemical analysis. Next, diversity indices and richness were calculated and multivariate analyses were used to establish relationships between the mesofauna, soil attributes and management. In the soil, mites were more abundant in the agricultural systems than in the forest, but the springtails, sensitive to low moisture and high temperature, were more abundant in the forest. Diversity and richness were higher in soil from the forest than under other systems. In no-tillage, there was a lower density of soil mesofauna, however, under this system, many invertebrates live in litter, since litter is the main food resource for them. In forest litter, we found lower invertebrate density and higher diversity than in no-tillage. Carbon, basic cations, $\mathrm{pH}$, $\mathrm{Al}$ and $\mathrm{V} \%$ were the attributes that best explained fauna variability in the systems.

Keywords: diversity, no-tillage, multivariate analysis, fauna density, mites

\section{Introduction}

Soil mesofauna consist of small invertebrates between 0.2 and $2 \mathrm{~mm}$ in body length that live in soil or litter. These invertebrates, mainly mites and collembolans, actively control nutrient cycling through frequent predation on nematodes, protozoa and fungi. Most of the mesofauna interactions with microorganisms are mutualistic, since these invertebrates fragment and moisten the plant residue when passing through their gastrointestinal tract, which are then excreted as fecal pellets (Lavelle, 1997; Moreira et al., 2008). These pellets, when in contact with the soil, are colonized by chemio-organotrophic microorganisms, which release mineral nutrients into the soil, especially ammonium ions, which can be absorbed by plants (Hendrix, 2000).

When soil is constantly revolved and uncovered and machine traffic is intense, we expect a lower abundance and diversity of soil organisms, due to the loss of soil and nutrients resulting in a decrease of niches and habitats for soil invertebrates (Aquino et al., 2008). In natural environments, we expect greater diversity and abundance of soil organisms than in agricultural crops, because fluctuations in temperature and moisture in soil are smaller and there is a greater diversity of coexisting plant species. A high diversity of litter in different stages of decomposition provides a greater diversity of niches for occupation by soil organisms (Makulec et al., 2006; Morais et al., 2010). Therefore, we assume that conservationist managements, like minimum tillage and no-tillage systems may present higher density and diversity of soil invertebrates than conventional systems of production.

In this study, our aims were to establish possible mesofaunal relationships with soil chemical attributes, litter, soil management and seasonality and to verify the density and diversity of soil mesofauna in no-tillage, minimum tillage, conventional tillage and native forest in order to understand how consolidated management systems and/or seasonality alter the community of soil invertebrates.

\section{Materials and Methods}

The study site was located in the region of Campos Gerais, Ponta Grossa, PR, at latitude $25^{\circ} 27^{\prime} \mathrm{S}$ and longitude $49^{\circ} 93^{\prime} \mathrm{W}$ at $875 \mathrm{~m}$ of elevation. According to the Köppen climate classification, the region has a subtropi$\mathrm{cal} \mathrm{Cfb}$ climate, characterized by average annual temperatures close to $21^{\circ} \mathrm{C}$, with a daily thermal amplitude between $9{ }^{\circ} \mathrm{C}$ and $13{ }^{\circ} \mathrm{C}$, and total annual rainfall between 1,300 and $1,800 \mathrm{~mm}$, with uniformly distributed rainfall throughout the year (Caviglione et al., 2000).

For the present study, the following three types of land use systems were considered that were maintained for 30 years in a Geric Ferralsol (rhodic) according to FAO (FAO, 2006): no-tillage (NT), conventional tillage $(\mathrm{CT})$, minimum tillage $(\mathrm{MT})$ and a native forest $(\mathrm{NF})$, 
which was used as a reference. The CT was plowed with a disk and two light harrows, while the MT was plowed with a Rome grade (to revolve and incorporate organic residues only in the planting line) and two light harrows. Under no-till, there was no soil mobilization.

The dimensions of the experimental plots under CT and MT managements were $100 \times 50 \mathrm{~m}$, and, under no-tillage, $100 \times 100 \mathrm{~m}$, with slopes of 7.7 and $8 \%$, respectively. Under these agricultural systems we have performed the following crop succession since 1995: maize - black oat - wheat - black oat - vetch (Table 1). Under all these systems, herbicides were frequently applied to control weed proliferation, especially Digitaria horizontalis and Brachiaria plantaginea. The NF was a remnant of mixed ombrophilous forest and occupied an adjacent area with $100 \times 100 \mathrm{~m}$.

Four samplings were taken from each land use system in winter, spring, summer and autumn respectively, from Aug 2010 to May 2011 (Figure 1). In winter, the areas were seeded with black oats, while in spring oats were toppled and soybeans sown. In summer, the areas were cultivated with soybeans and in autumn, soybeans were harvested. NT presented more than 15 $\mathrm{cm}$ of homogeneous litter, while CT presented no litter. MT presented a diffused and thin layer of litter over the soil and NF presented approximately $10 \mathrm{~cm}$ of heterogeneous litter.

Under each management system and in the forest, two parallel transects were drawn, disregarding the edge of the plots, maintaining a distance of $20 \mathrm{~m}$ from the border. Five equidistant soil samples with metal rings were collected ( $5 \mathrm{~cm}$ diameter and $5 \mathrm{~cm}$ height) in each transect, totaling ten soil samples per land use system. Simultaneously, in NF and NT, eight samples of litter were collected from a wooden square delimiting an area of $25 \times 25 \mathrm{~cm}$, to evaluate soil mesofauna abundance and diversity.

Table 1 - Crop succession since 1995 and history of agrochemical use in no-tillage (NT), minimum tillage (MT) and conventional tillage (CT).

\begin{tabular}{|c|c|c|}
\hline Crops & & Agrochemicals \\
\hline \multirow{3}{*}{ Year 1} & Maize & $300 \mathrm{~kg} \mathrm{ha}^{-1}$ NPK (4-30-10). \\
\hline & Black oat & $\begin{array}{l}80 \mathrm{~kg} \mathrm{ha}^{-1} \text { of seeds; without fertilization; } \\
\text { desiccated with fosfonometil glycine in NT; } \\
\text { and trifluralin application in CT and MT after } \\
\text { soil plowing. }\end{array}$ \\
\hline & Soybean & $\begin{array}{l}300 \mathrm{~kg} \mathrm{ha}^{-1} \mathrm{NPK}(0-16-12) ; \text { fomesafem and } \\
\text { cletodim application. }\end{array}$ \\
\hline \multirow{3}{*}{ Year 2} & Wheat & $\begin{array}{l}300 \mathrm{~kg} \mathrm{ha}^{-1} \mathrm{NPK}(4-30-10) \text {; desiccated with } \\
\text { fosfonometil glycine in NT; and trifluraline and } \\
\text { metribuzim application in CT and MT after soi } \\
\text { plowing. }\end{array}$ \\
\hline & Soybean & $\begin{array}{l}300 \mathrm{~kg} \mathrm{ha}^{-1} \mathrm{NPK}(0-16-12) ; \text { fomesafen and } \\
\text { cletodim application. }\end{array}$ \\
\hline & Black oat and vetch & $\begin{array}{l}32 \mathrm{~kg} \mathrm{ha}^{-1} \text { of black oat seeds and } 44 \mathrm{~kg} \mathrm{ha}^{-1} \\
\text { of vetch seeds; desiccated with fosfonometil } \\
\text { glycine in NT; and atrazine and S-metolachlor } \\
\text { application in CT and MT after soil plowing. }\end{array}$ \\
\hline
\end{tabular}

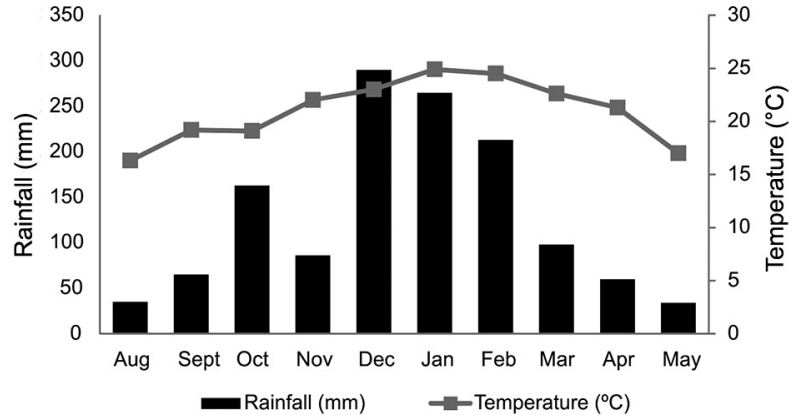

Figure 1 - Rainfall and mean monthly temperatures during the sampling period of soil and litter from Aug 2010 to May 2011, in Ponta Grossa, in the state of Paraná, Brazil. Sampling period: Aug (winter), Nov (spring), Feb (summer) and May (autumn).

At each sampling point, soil samples were also taken for chemical analyses, which were carried out according to Embrapa (2011). These samples were sieved ( $2 \mathrm{~mm}$ mesh) and homogenized for subsequent determination for the following parameters: $\mathrm{pH}$ in calcium chloride $\left(\mathrm{CaCl}_{2}\right)$, Phosphorus (P) (extraction with Mehlich 1), Potassium $(\mathrm{K})$ and Sodium $(\mathrm{Na})$ (Extraction with dilute $\mathrm{HCl})$, Calcium (Ca), Magnesium (Mg) and Aluminum (Al) (extraction with $1 \mathrm{~N} \mathrm{KCl})$, potential acidity $(\mathrm{H}+\mathrm{Al})$ (extraction with calcium acetate). Total organic carbon was determined by wet oxidation of the organic matter. The cation exchange capacity (CEC) was calculated at $\mathrm{pH} 7$, the saturation of the cationic complex by bases $(\mathrm{V} \%)$ and by aluminum $(\mathrm{m} \%)$, and the sum of bases $(\mathrm{SB})$.

Mesofauna was extracted from the soil and litter using Berlese funnels. The samples were maintained for seven days in these funnels and then the invertebrates were counted and identified under the stereomicroscope (Aquino et al., 2006). All the invertebrates that passed through the $2 \mathrm{~mm}$ mesh of Berlese funnels were considered mesofauna since they measured between 0.2 and $2 \mathrm{~mm}$ in body diameter (Lavelle, 1997; Hendrix, 2000). Subsequently, the density of soil invertebrates (individuals $\mathrm{m}^{-2}$ ) was calculated based on the dimensions of the sampling areas (metal rings for soil and wooden squares for litter). In order to evaluate the invertebrate diversity, the richness (mean number of total orders sampled) and Simpson's diversity index were calculated using the equation: $S=1-D$ (Magurran, 2004). Orders that accounted for less than $5 \%$ of the total density in soil or litter were categorized as "others". All sampled orders are shown in tables of absence and presence for both soil and litter.

The Kolmogorov-Smirnov test was used to verify the normality of the data. When data were not normal, we used the transformation $\log (x+1)$ to reach the normal distribution. The chemical and biological attributes were analyzed using the analysis of variance and Tukey's test $(p<0.05)$ for comparison of means. The redundancy analysis (RDA) associated with the Monte Carlo test $(p<0.05)$ for the two first axes of analysis 
and each chemical variable was used to establish the correlations between chemical and biological attributes of the soil and their respective managements. Biological and chemical attributes were defined as response and explanatory variables, respectively.

\section{Results and Discussion}

\section{Soil chemical analyses}

NT and NF had higher carbon content than other land use systems. These systems may present a complex food chain due mainly to the higher accumulation of litter, which results in lower soil losses due to erosion, lower carbon losses as $\mathrm{CO}_{2}$, and consequently, accumulation of $\mathrm{C}$ in the soil surface layers (Mafra et al., 2008; Siqueira Neto et al., 2009) (Table 2), which could serve as food to diverse soil organisms.

In the agricultural sites, the use of mineral fertilization was frequent (Table 1), which increased P levels when compared to soils with native vegetation (Table 2) which had a higher $\mathrm{K}$ content than the evaluated agricultural systems, possibly due to the high leaching potential of $\mathrm{K}$. This element is very often lost when the crop is removed (Pathak et al., 2010; Rosolem and Steiner, 2017).

In the forest soils, where no herbicide and no fertilization are applied, $\mathrm{Al}$ levels were higher compared to the other agricultural systems (Table 2), since $\mathrm{Al}$ is one of the most persistent elements in highly weathered tropical soils without fertilization (Silva et al., 2017). Due to its high potential acidity, NF also presented a higher potential CEC than the other land use systems evaluated (Table 2).

\section{Mesofauna in soil}

In the soil, a higher density of collembolans in NF and MT than in NT was found (Table 3). These invertebrates are very dependent on soil moisture and take advantage of the pores and cracks to burrow into the soil

Table 2 - Chemical attributes of soil in 0-5 cm layer under conventional tillage (CT), no-tillage (NT), minimum tillage (MT) and in native forest (NF) in Ponta Grossa, in the state of Paraná, Brazil.

\begin{tabular}{lcccrr}
\hline Attributes & & $\mathrm{CT}$ & $\mathrm{NT}$ & $\mathrm{MT}$ & \multicolumn{1}{c}{$\mathrm{NF}$} \\
\hline $\mathrm{C}$ & $\mathrm{g} \mathrm{dm}^{-3}$ & ${ }^{*} 27.63 \mathrm{~b}$ & $39.76 \mathrm{a}$ & $31.63 \mathrm{~b}$ & $46.24 \mathrm{a}$ \\
$\mathrm{P}$ & $\mathrm{mg} \mathrm{dm}^{-3}$ & $7.30 \mathrm{bc}$ & $21.58 \mathrm{a}$ & $8.68 \mathrm{~b}$ & $4.16 \mathrm{c}$ \\
$\mathrm{Al}^{3+}$ & & $0.48 \mathrm{~b}$ & $0.53 \mathrm{ab}$ & $0.42 \mathrm{~b}$ & $1.13 \mathrm{a}$ \\
$\mathrm{H}+\mathrm{Al}$ & & $8.17 \mathrm{~b}$ & $10.18 \mathrm{ab}$ & $8.24 \mathrm{~b}$ & $11.97 \mathrm{a}$ \\
$\mathrm{Ca}^{2}+$ & & $2.57 \mathrm{a}$ & $3.31 \mathrm{a}$ & $2.96 \mathrm{a}$ & $3.67 \mathrm{a}$ \\
$\mathrm{Mg}^{2+}$ & $\mathrm{cmolc} \mathrm{dm}^{-3}$ & $1.08 \mathrm{~b}$ & $1.35 \mathrm{ab}$ & $1.22 \mathrm{ab}$ & $1.67 \mathrm{a}$ \\
$\mathrm{K}$ & & $0.22 \mathrm{ab}$ & $0.24 \mathrm{ab}$ & $0.20 \mathrm{~b}$ & $0.32 \mathrm{a}$ \\
$\mathrm{SB}$ & & $3.87 \mathrm{a}$ & $4.91 \mathrm{a}$ & $4.39 \mathrm{a}$ & $5.67 \mathrm{a}$ \\
$\mathrm{CEC}$ & & $12.18 \mathrm{c}$ & $15.09 \mathrm{~b}$ & $12.63 \mathrm{c}$ & $17.65 \mathrm{a}$ \\
$\mathrm{V}$ & $\%$ & $33.15 \mathrm{a}$ & $32.42 \mathrm{a}$ & $34.50 \mathrm{a}$ & $32.07 \mathrm{a}$ \\
$\mathrm{m}$ & $\%$ & $11.58 \mathrm{a}$ & $10.37 \mathrm{a}$ & $10.01 \mathrm{a}$ & $22.08 \mathrm{a}$ \\
$\mathrm{pH}$ & & $4.34 \mathrm{a}$ & $4.33 \mathrm{a}$ & $4.4 \mathrm{a}$ & $4.24 \mathrm{a}$ \\
\hline
\end{tabular}

${ }^{*}$ Means followed by the same letter in line do not differ between land use systems. Tukey's test $(p<0.05)$. V\% $=$ saturation of the cationic complex by bases; $m \%$ = saturation of the cationic complex by aluminum; SB = Sum of bases; $\mathrm{CEC}=$ cation exchange capaity. profile (Hendrix, 2000; Choi et al., 2006). In the category "other invertebrates", NF had a higher density than other systems, most likely due to greater plant diversity. Consequently, organic compounds at different stages of decomposition may offer multiple niches for colonization by a variety of species. Additionally, a lower mite density was found in samples in NF than in the other agricultural systems. All these findings contributed to higher values of richness and Simpson's diversity in NF. The higher diversity in forest is probably due to the higher diversity of habitats and niches in this system, which allow for higher uniformity and richness of mesofauna groups than in agricultural systems.

In winter, when the areas were cultivated with black oats, a higher density of soil mesofauna in MT $\left(19,771\right.$ ind $\left.\mathrm{m}^{-2}\right)$ relative to $\mathrm{NT}\left(7,032\right.$ ind $\left.\mathrm{m}^{-2}\right)$ was found. In spring, when soybean was budding, a higher density of soil mesofauna in NT was observed $(20,637$ ind $\left.\mathrm{m}^{-2}\right)$ than in forest $\left(9,631\right.$ ind $\left.\mathrm{m}^{-2}\right)$ and especially in CT $\left(3,567\right.$ ind $\left.\mathrm{m}^{-2}\right)$. The increase in soil mesofauna density in MT and NT is mostly due to the higher density of the Acarina and Collembola sampled during these seasons. In summer, when soybeans were completely developed, there was a reduction in the density of soil mesofauna in all systems, and no statistical differences were observed. On the other hand, in autumn, after the soybean harvest, a higher density of soil mesofauna was established in MT relative to NT (Figure 2).

A reduction in soil mesofauna density going from winter into summer was observed, except in NT. During spring, after soybean seeding, this system had the highest density of soil mesofauna $\left(20,637\right.$ ind $\left.\mathrm{m}^{-2}\right)$. In autumn, after the soybean harvest, there was an increase in soil mesofauna density in all land use systems (Figure 2).

Table 3 - Soil mesofauna density (invertebrates $\mathrm{m}^{-2}$ ) and diversity in soil and litter under no-tillage (NT), minimum tillage (MT), conventional tillage (CT) and in native forest (NF) in Ponta Grossa, in the state of Paraná, Brazil.

\begin{tabular}{|c|c|c|c|c|}
\hline \multicolumn{5}{|c|}{ Soil } \\
\hline & NF & NT & CT & MT \\
\hline Acarina & * 4,318 b & $7,541 \mathrm{a}$ & $6,865 \mathrm{a}$ & 9,223 a \\
\hline Collembola & 1,975 a & 535 b & $1,557 \mathrm{ab}$ & $1,783 \mathrm{a}$ \\
\hline Others & $2,191 \mathrm{a}$ & $675 b$ & 552 b & $510 b$ \\
\hline Total & 8,739 a & $9,134 \mathrm{a}$ & $9,271 \mathrm{a}$ & $11,707 \mathrm{a}$ \\
\hline Simpson's Index & $0.57 \mathrm{a}$ & $0.26 \mathrm{~b}$ & 0.37 b & $0.33 \mathrm{~b}$ \\
\hline Richness & $7.3 \mathrm{a}$ & $5.1 \mathrm{~b}$ & $4.9 \mathrm{~b}$ & $5.1 b$ \\
\hline \multicolumn{5}{|c|}{ Litter } \\
\hline Acarina & 316 b & $1,657 a$ & - & - \\
\hline Collembola & $135 \mathrm{~b}$ & $431 \mathrm{a}$ & - & - \\
\hline Isopoda & $55 a$ & $5 b$ & - & - \\
\hline Hymenoptera & $105 \mathrm{a}$ & $33 a$ & - & - \\
\hline Others & $174 a$ & $146 a$ & - & - \\
\hline Total & $680 \mathrm{~b}$ & $2,238 a$ & - & - \\
\hline Simpson's Index & 0.68 a & $0.46 \mathrm{~b}$ & - & - \\
\hline Richness & $9.5 \mathrm{a}$ & $10.0 \mathrm{a}$ & - & - \\
\hline
\end{tabular}


The orders Acarina, Collembola and Psocoptera were present in soil for all systems evaluated during the four sampling seasons. Amphipoda were detected only in soil samples in NF (Table 4). These microcrustaceans live commonly in terrestrial environments, and are usually associated with high soil moisture. Their presence is related to soil respiration rates, presumably due to the consumption of organic compounds and the physical effects of their locomotion, which causes a greater clearance of soil and litter particles, opening spaces in the soil surface, which helps diffuse $\mathrm{CO}_{2}$ into the atmosphere (Friend and Richardson, 1986).

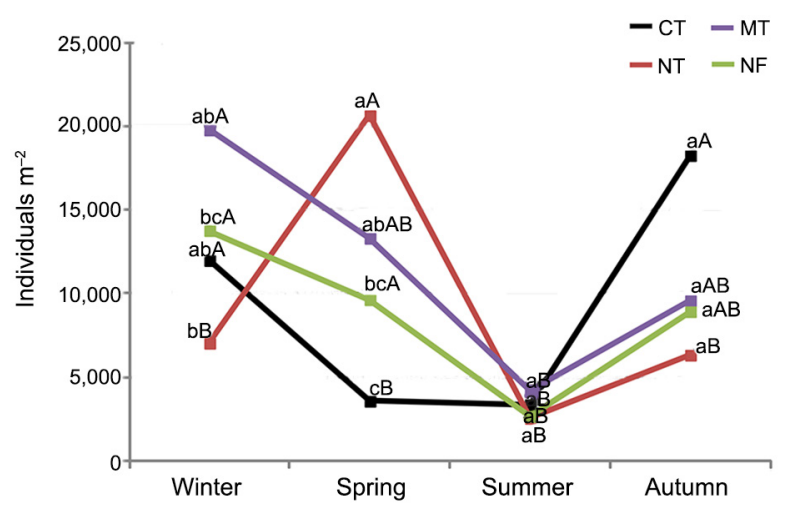

Figure 2 - Soil mesofauna density in soil under no-tillage (NT), minimum tillage (MT), conventional tillage (CT) and in native forest (NF) in Ponta Grossa, in the state of Paraná, Brazil. Different capital letters indicate statistical differences between seasons, while small letters indicate statistical differences between land use systems (Tukey's test $p<0.05$ ).
Thirteen orders of soil invertebrates were detected in winter, as well as in spring and autumn, and eleven orders in summer. The highest richness was present in $\mathrm{NF}$, with thirteen identified orders and the lowest in NT and MT, with only six identified orders (Table 4).

Redundancy analysis explained $47 \%$ of the data variation, with $34 \%$ of the data variation explained by the first two axes. Among these, $99 \%$ were explained by the relationship between the mesofauna groups and the chemical soil attributes. The Monte Carlo permutation was significant $(p<0.05)$ for the first two axes and for all axes of the RDA. The only significant explanatory variables were V\% (saturation of the CEC by basic cations) and available $\mathrm{Al}$ in soil solution (Figure 3).

The order Acarina and the total fauna abundance, represented mostly by mites, correlated positively with $\mathrm{pH}, \mathrm{V} \%$, calcium and with the sum of bases (Figure 3), since the mites were the dominant group in all the land use systems studied and they prefer alkaline environments for development (Pérez et al., 2014).

Collembola, "other invertebrates", species richness, and Simpson's diversity correlated positively with Carbon, Aluminum, potential acidity and Potassium contents in soil, especially in samples from native forest (Figure 3). Soils under native vegetation are usually poor in mineral nutrients and present high acidity, since fertilizers are not applied and $\mathrm{pH}$ is not corrected. However, these soils have varied and numerous niches and high microbial activity, which support higher diversity of soil fauna than agricultural sites (Rosa et al., 2015).

Additionally, collembolans prefer fresh organic matter as a food source (Lavelle, 1997; Hendrix, 2000) and they are positively correlated with $\mathrm{C}$ content. Dif-

Table 4 - Invertebrate orders identified in soil under no-tillage (NT), conventional tillage (CT), minimum tillage (MT) and in native Forest (NF) in four seasons in Ponta Grossa, in the state of Paraná, Brazil.

\begin{tabular}{|c|c|c|c|c|c|c|c|c|c|c|c|c|c|c|c|c|}
\hline \multirow{3}{*}{ Orders } & \multicolumn{16}{|c|}{ Seasons } \\
\hline & \multicolumn{4}{|c|}{ Winter (Richness=13) } & \multicolumn{4}{|c|}{ Spring (Richness=13) } & \multicolumn{4}{|c|}{ Summer (Richness=11) } & \multicolumn{4}{|c|}{ Autumn (Richness=13) } \\
\hline & NT & CT & MT & $\mathrm{NF}$ & NT & CT & MT & $\mathrm{NF}$ & NT & CT & MT & $\mathrm{NF}$ & NT & CT & MT & $\mathrm{NF}$ \\
\hline Acarina & $x$ & $x$ & $x$ & $x$ & $x$ & $x$ & $x$ & $x$ & $x$ & $x$ & $x$ & $x$ & $x$ & $x$ & $x$ & $X$ \\
\hline Collembola & $x$ & $x$ & $x$ & $x$ & $x$ & $x$ & $x$ & $x$ & $x$ & $x$ & $x$ & $x$ & $x$ & $x$ & $x$ & $x$ \\
\hline Diplura & & $x$ & & & & $x$ & & & & & & & $x$ & $x$ & & $x$ \\
\hline Chilopoda & & $x$ & & & $x$ & & & & & & $x$ & $x$ & $x$ & $x$ & $x$ & $x$ \\
\hline Protura & & $x$ & & $X$ & & & & & & $\mathrm{x}$ & $x$ & $x$ & $x$ & $x$ & $x$ & $x$ \\
\hline Psocoptera & $X$ & $x$ & $x$ & $x$ & $X$ & $X$ & $x$ & $X$ & $X$ & $x$ & $x$ & $x$ & $x$ & $x$ & $x$ & $X$ \\
\hline Coleoptera & $x$ & $x$ & & & & $x$ & $x$ & $x$ & & $x$ & & & & $x$ & & $x$ \\
\hline Isopoda & & & & & & & & & & & & & & & & $X$ \\
\hline Hymenoptera & $x$ & & $x$ & $x$ & $x$ & & & $x$ & $x$ & & $x$ & $x$ & & & $x$ & $x$ \\
\hline Araneae & & $x$ & & $x$ & & & & & & $x$ & & & & & $x$ & $x$ \\
\hline Simphyla & & $x$ & $X$ & $x$ & & & & & & $x$ & & $x$ & & & & $x$ \\
\hline Thysanoptera & $x$ & $x$ & $x$ & $x$ & & & $x$ & & & & & & & & & $X$ \\
\hline Heteroptera & & & & & $x$ & $x$ & & & $x$ & $x$ & $x$ & $X$ & & & & \\
\hline Pauropoda & & & & & & & & & $x$ & & & & & & & $X$ \\
\hline Diplopoda & & & & $x$ & $x$ & & & $x$ & & & & & & & & \\
\hline Isopoda & & & & $x$ & & & & $x$ & & & & & & & & \\
\hline Blattodea & & & & & $x$ & & & $x$ & & & & & & & & \\
\hline Amphipoda & & & & & & & & $x$ & & & & & & & & \\
\hline Richness & 6 & 10 & 6 & 10 & 8 & 6 & 5 & 9 & 6 & 8 & 7 & 8 & 6 & 7 & 7 & 13 \\
\hline
\end{tabular}


ferent carbon sources deposited on the soil at various stages of decomposition can lead to the development of a richer and more diversified community of soil invertebrates than environments maintained under agricultural systems (Moço et al., 2005; Battirola et al., 2007). The soil covered by leaf litter in forest systems promotes higher soil moisture and lower temperature than soil under agricultural systems (Achat et al., 2015) which explains the higher occurrence of collembolans in NF, since these conditions favor collembolan reproduction and development (Choi et al., 2006).

\section{Mesofauna in litter}

In the litter, a higher total density of mesofauna was found in NT than in NF, mainly composed of mites and springtails (five and three times higher in NT, respectively), but there was a reduction in diversity (Simpson's index) in NT relative to NF (Table 3).

The density of Isopoda, on the other hand, was higher in NF (ten times higher in NF than in NT) (Table 3). These crustaceans correlated with increasing litter moisture, since they are terrestrial animals that breathe

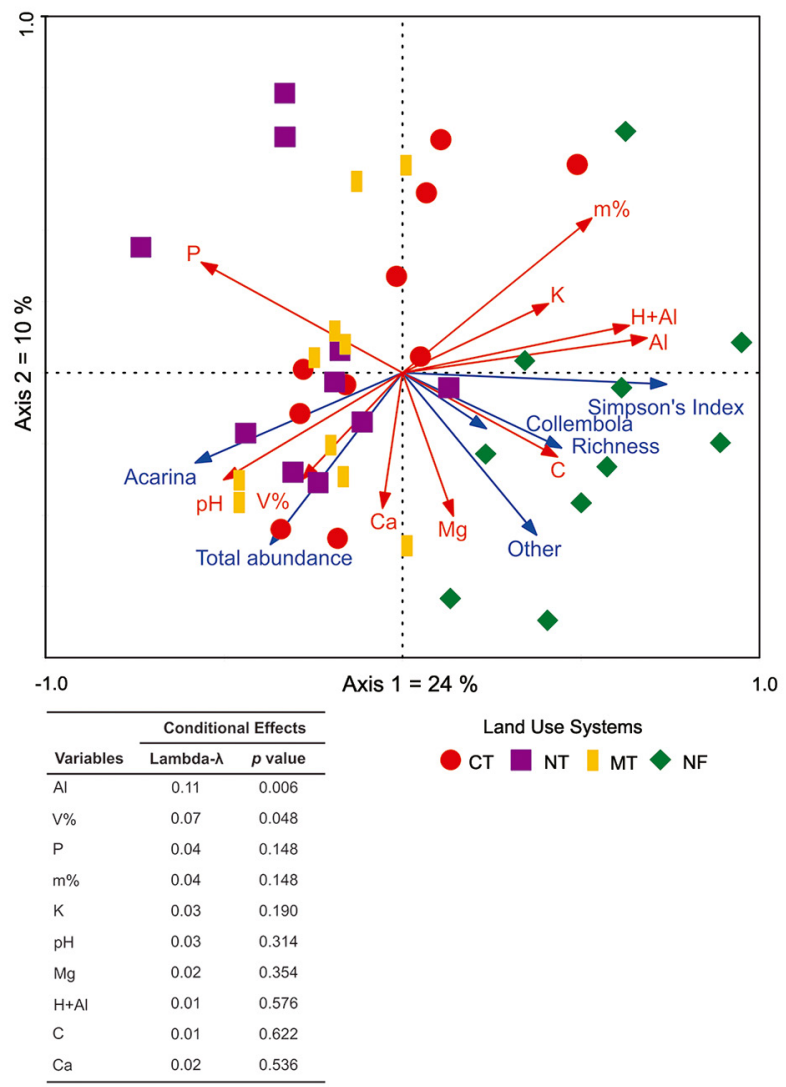

Figure 3 - Redundancy Analysis (RDA) with soil mesofauna abundance and diversity, like response variables (blue letters) and chemical attributes, like explanatory variables (red letters) in no-tillage (NT), minimum tillage (MT), conventional tillage (CT) and native forest (NF) in Ponta Grossa, in the state of Paraná, Brazil. through gills requiring more moisture in the litter (Correia et al., 2008). It is known that NF generally has a greater diversity of niches compared to other agricultural systems (Rosa et al., 2015) which, however, does not imply a higher mesofauna density, since results showed higher diversity and lower mesofauna density in NF then in NT. It is possible that the less diversified litter in NT attracted a higher abundance of mites and collembolans, which contributed to the lower Simpson's index in NT (Table 3).

When NT was cultivated with black oat for soil cover, more than $40 \%\left(4,046\right.$ ind $\left.\mathrm{m}^{-2}\right)$ of mesofauna sampled was in litter (Figure 4). After the toppling of black oats, a great reduction in the density of mesofauna in litter $\left(252\right.$ ind $\left.\mathrm{m}^{-2}\right)$ and a peak in soil $(20,637$ ind $\mathrm{m}^{-2}$ ) was observed. When soybeans were completely developed, 2,868 ind $\mathrm{m}^{-2}$ in litter and 3,577 in soil were sampled, and after the harvest, there was a reduction in mesofauna density in litter $\left(1,774\right.$ ind $\left.\mathrm{m}^{-2}\right)$ and an increase in soil $\left(6,318\right.$ ind $\left.\mathrm{m}^{-2}\right)$. Thus, it was possible to verify a decrease in mesofauna in litter when the machine traffic is intense and when the crops are not yet completely established in NT, while the inverse occurs in soil. These effects on the mesofauna community were accompanied by seasonal changes, since in winter (Aug) when the weather is cold and dry (Figure 1), most of the soil invertebrates were found in litter. During summer, under higher temperatures and moisture, most of the soil invertebrates inhabited the soil (Figures 2 and 4). Thus, there is a definite influence of the crop cultivated, management and seasonality on the density and composition of the soil invertebrate community.

We found the orders Acarina, Collembola, Psocoptera, Isopoda and Araneae in litter at all sampling times in NF and NT. The order Orthoptera was present only in summer in both systems, whereas the order Dermaptera was present only in NT (Table 5). The order Dermaptera has positive tigmotropism, since it frequently seeks con-

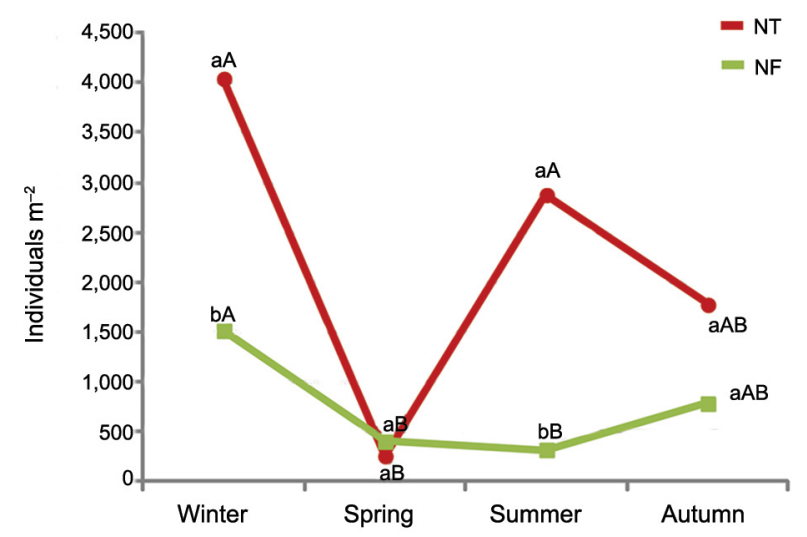

Figure 4 - Soil mesofauna density in litter under no-tillage (NT) and in native forest (NF) in Ponta Grossa, in the state of Paraná, Brazil. Different capital letters indicate statistical differences between seasons, while small letters indicate statistical differences between land use systems (Tukey's test $p<0.05$ ). 
Table 5 - Invertebrate orders identified in litter under no-tillage (NT) and in native Forest (NF) in four seasons in Ponta Grossa, in the state of Paraná, Brazil.

\begin{tabular}{|c|c|c|c|c|c|c|c|c|}
\hline \multirow{3}{*}{ Orders } & \multicolumn{8}{|c|}{ Seasons } \\
\hline & \multicolumn{2}{|c|}{ Winter (Richness=15) } & \multicolumn{2}{|c|}{ Spring (Richness=17) } & \multicolumn{2}{|c|}{ Summer (Richness=16) } & \multicolumn{2}{|c|}{ Autumn (Richness=15) } \\
\hline & NT & $\mathrm{NF}$ & NT & NF & NT & $\mathrm{NF}$ & NT & $\mathrm{NF}$ \\
\hline Acarina & $x$ & $x$ & $x$ & $x$ & $x$ & $x$ & $x$ & $x$ \\
\hline Collembola & $x$ & $x$ & $x$ & $x$ & $x$ & $x$ & $x$ & $x$ \\
\hline Blattodea & & $x$ & & $x$ & $x$ & $x$ & & \\
\hline Coleoptera & $x$ & & $x$ & $x$ & $x$ & $x$ & $x$ & $x$ \\
\hline Heteroptera & $x$ & $x$ & & $x$ & $x$ & & $x$ & $x$ \\
\hline Hymenoptera & $x$ & $x$ & $x$ & $x$ & $x$ & $x$ & $x$ & $x$ \\
\hline Psocoptera & $x$ & $x$ & $x$ & $x$ & $x$ & $x$ & $x$ & $x$ \\
\hline Thysanoptera & & & & $x$ & & & $x$ & \\
\hline Aranea & $x$ & $x$ & $x$ & $x$ & $x$ & $x$ & $x$ & $x$ \\
\hline Opilionida & & & & $x$ & & & & \\
\hline Pseudoscorpiones & & & & $x$ & & & & $x$ \\
\hline Amphipoda & & $x$ & & $x$ & $x$ & $x$ & $x$ & $x$ \\
\hline Isopoda & $x$ & $x$ & $x$ & $x$ & $x$ & $x$ & $x$ & $x$ \\
\hline Diplura & & & $x$ & & & & & \\
\hline Thysanoptera & $x$ & $x$ & $x$ & & & & & $x$ \\
\hline Diplopoda & $x$ & & $x$ & & $x$ & & $x$ & \\
\hline Chilopoda & $x$ & $x$ & $x$ & & $x$ & & & \\
\hline Protura & & $x$ & & & $x$ & & $x$ & \\
\hline Simphyla & & $x$ & & & $x$ & & & \\
\hline Orthoptera & & & & & $x$ & $x$ & & \\
\hline Dermaptera & & & & & $x$ & & $x$ & \\
\hline Richness & 11 & 13 & 11 & 13 & 16 & 10 & 13 & 11 \\
\hline
\end{tabular}

tact with surfaces, inhabiting all types of moist cracks. This order was favored by living in crop residues deposited in the NT system. Additionally, these invertebrates are omnivorous and can feed on plant tissues, smaller invertebrates and fungal mycelia, which are more abundant in systems that have a higher moisture content (Cranston and Gullan, 2008).

On the other hand, Orthoptera has a great affinity with warmer and humid climates. The litter may provide food for crickets, such as leaves, flowers, fungi and fruits, and it may provide free spaces to hide from natural enemies (Gangwere, 1961; Szinwelski et al., 2015). Therefore, the increase in rain and temperature in summer seems to favor the abundance of these insects, since seasonal cycles of tropical insects have been attributed to the variation in resource availability caused by alternating between dry and rainy periods (Oliveira et al., 2013; Neves et al., 2010).

\section{Conclusions}

In natural systems, there is a higher diversity of soil invertebrates than in agricultural systems. The total density of soil mesofauna did not differ between land use systems; however, in spring, NT presented a higher mesofauna density than other agricultural systems. In winter, however, the abundance of soil mesofauna in plowed systems was higher and decaying going into summer, finally reaching a new increase in abundance in autumn.

A greater litter diversity on the soil surface favors a greater diversity of soil invertebrates, but does not necessarily define higher or lower abundance.
It is possible that higher carbon contents in soil increase mesofauna diversity, especially in NF. Depending on the climatic conditions and the crop cultivated, soil mesofauna may use litter and/or soil as a shelter. Harvest operations and absence of agricultural crops reduce mesofauna density in litter, while lower temperatures and lower moisture reduce mesofauna density in soil, but not necessarily in litter.

\section{Acknowledgments}

The authors thank M.Sc. Maria Rosa Quintans Lopez for her collaboration during the development of this research, and acknowledge her great contribution to the diffusion of knowledge on soil invertebrates. Elke Jurandy Bran Nogueira Cardoso extends thanks for a productivity grant provided by Conselho Nacional de Desenvolvimento Científico e Tecnológico (CNPq) and for the Fundação de Amparo a Pesquisa do Estado de São Paulo (FAPESP), process number: 2016/18944-3

\section{Authors' Contributions}

Conceptualization: Zagatto, M.R.G., Pereira, A.P.A., Estrada-Bonilla, G., Cardoso, E.J.B.N. Data acquisition: Zagatto, M.R.G., Zanão Junior, L.A. Data analysis: Zagatto, M.R.G., Zanão Junior, L.A. Design of Methodology: Zanão Junior, L.A. Writing and Editing: Zagatto, M.R.G., Zanão Junior, L.A., Pereira, A.P.A., Estrada-Bonilla, G., Cardoso, E.J.B.N. 


\section{References}

Achat, D.L.; Deleuze, C.; Landmann, G.; Pousse, N.; Ranger, J.; Augusto, L. 2015. Quantifying consequences of removing harvesting residues on forest soil and tree growth: a metaanalysis. Forest Ecology and Management 348: 124-141.

Aquino, A.M.; Correia, M.E.F.; Badejo, M.A. 2006. Sampling of Soil Mesofauna Using Modified Berlese-Tulgren Funnels $=$ Amostragem da Mesofauna Edáfica Utilizando Funis de Berlese-Tulgren Modificados. Embrapa Agrobiologia, Seropédica, RJ, Brazil (in Portuguese).

Aquino, A.M.; Correia, M.E.F.; Guimarães, M.F.; Lavelle, P.; Mercante, F.M.; Silva, R.F. 2008. Invertebrate soil macrofauna under different ground cover plants in the no-till system in the Cerrado. European Journal of Soil Biology 44: 191-197.

Battirola, L.D.; Adis, J.; Marques, M.I.; Silva, F.H.O. 2007. Arthropod community associated with the canopy of Attalea phalerata Mart. (Arecaceae) during the flood period of the Pantanal of Poconé, MT. Neotropical Entomology 36: 640-651 (in Portuguese, with abstract in English).

Caviglione, J.H.; Kiihl, L.R.B.; Caramori, P.H.; Oliveira, D. 2000. Climate Maps of Paraná = Cartas Climáticas do Paraná. Instituto Agronômico do Paraná, Londrina, PR, Brazil (in Portuguese).

Choi, W.; Moorhead, D.L.; Neher, D.A.; Ryoo, M. 2006. A modeling study of soil temperature and moisture effects on population dynamics of Paronychiurus kimi (Collembola: Onychyuridae). Biology and Fertility of Soils 43: 69-75.

Correia, M.E.F.; Aquino, A.M.; Aguiar-Menezes, E.L. 2008. Ecological Aspects of Terrestrial Isopoda $=$ Aspectos Ecológicos dos Isopoda Terrestres. Embrapa Agrobiologia, Seropédica, RJ, Brazil (in Portuguese).

Cranston, P.S.; Gullan, P.J. 2008. The Insects = Os Insetos. Editora Roca, São Paulo, SP, Brazil (in Portuguese).

Empresa Brasileira de Pesquisa Agropecuária [Embrapa]. 2011. Manual of Soil Analysis Methods = Manual de Métodos de Análises de Solo. Embrapa, Rio de Janeiro, Brazil (in Portuguese).

Food and Agriculture Organization [FAO]. 2006. World Reference Base for Soil Resources: A Framework for International Classification, Correlation and Communication. IUSS/ISRIC/FAO, Rome, Italy.

Friend, J.A.; Richardson, A.M.M. 1986. Biology of terrestrial amphipods. Annual Review of Entomology 31: 25-48.

Gangwere, S.K. 1961. A monograph on food selection in Orthoptera. Transactions of the American Entomology Society 87: 67-230.

Hendrix, P.F. 2000. Soil fauna. In: Sumner, M.E. Handbook of Soil Science. CRC Press, Boca Raton, FL, USA.

Lavelle, P. 1997. Faunal activities and soil processes: adaptive strategies that determine ecossystem function. Advances in Ecology Research 27: 93-132.

Mafra, A.L.; Guedes, S.F.F.; Klauberg Filho, O.; Santos, J.C.P.; Almeida, J.A.; Rosa, J.D. 2008. Organic carbon and soil chemical attributes in forest areas. Revista Árvore 32: 217-224 (in Portuguese, with abstract in English).

Magurran, A. 2004. Measuring Biological Diversity. Blackwell Science, Oxford, UK.

Makulec, K.I.; Olejniczak, I.; Szanser, M. 2006. Response of soil micro and mesofauna to diversity and quality of plant litter. European Journal of Soil Biology 42: 244-249.
Moço, M.K.S.; Correia, M.E.F.; Rodrigues, A.C.G.; Rodrigues, E.F.G. 2005. Characterizaton of soil fauna in different vegetation covers in the northern Fluminense region (RJ). Revista Brasileira de Ciência do Solo 29: 555-564 (in Portuguese, with abstract in English).

Morais, J.W.; Oliveira, V.S.; Dambros, C.S.; Tapia-Coral, S.C.; Acioli, A.N.S. 2010. Soil mesofauna in different systems of land use soil in upper river Solimões, AM, Brazil. Neotropical Entomology 39: 145-152 (in Portuguese, with abstract in English).

Moreira, F.M.S.; Siqueira, J.O.; Brussaard, L. 2008. Soil Biodiversity in Brazilian Ecosystems = Biodiversidade do Solo em Ecossistemas Brasileiros. Editora UFLA, Lavras, MG, Brazil (in Portuguese).

Neves, F.S.; Araujo L.S.; Espirito-Santo, M.M.; Fagundes, M.; Fernandes, G.W. 2010. Effect of forest stratification and secondary succession on the herbivorous insect fauna associated with the canopy of a deciduous seasonal forest $=$ Efeito da estratificação florestal e da sucessão secundária sobre a fauna de insetos herbívoros associada ao dossel de uma floresta estacional decidual. Biota 3: 33-44 (in Portuguese).

Oliveira, C.S.P.; Mendes, M.P.; Duarte, M.N.; Rodrigues, W.C. 2013. Composition and diversity of the crickets fauna (Orthoptera: Grylloidea) in a fragment of Atlantic rain forest in the Rio de Janeiro state. EntomoBrasilis 6: 184-192 (in Portuguese, with abstract in English).

Pathak, H.; Mohanty, S.; Jain, N.; Bhatia, A. 2010. Nitrogen, phosphorous, and potassium budgets in Indian agriculture. Nutrient Cycling in Agroecosystems 86: 287-299.

Pérez, T.M.; Guzmán-Cornejo, C.; Montiel-Parra, G.; ParedesLeon, R.; Rivas, G. 2014. Biodiversity of Acari in Mexico. Revista Mexicana de Biodiversidad 85: 399-407 (in Spanish, with abstract in English).

Rosa, M.G.; Klauberg Filho, O.; Bartz, M.L.C.; Mafra, A.L.; Sousa, J.P.F.A.; Baretta, D. 2015. Soil macrofauna and physical and chemical properties under soil management systems in the Santa Catarina highlands, Brazil. Revista Brasileira de Ciência do Solo 39: 1544-1553 (in Portuguese, with abstract in English).

Rosolem, C.A.; Steiner, F. 2017. Effects of soil texture and rates of $\mathrm{K}$ input on potassium balance in tropical soil. European Journal of Soil Science 68: 658-666.

Silva, A.C.; Souza, S.; Fabris, J.D.; Barbosa, M.S.; Barral, U.M.; Costa, R.V. 2017. Chemical-mineralogical characterization of magnetic materials from magnetic soils of the southern Espinhaço mountain chain and of the upper Jequitinhonha valley, state of Minas Gerais, Brazil. Revista Brasileira de Ciência do Solo 41: e0160274.

Siqueira Neto, M.; Venske Filho, S.P.; Piccolo, M.C.; Cerri, C.E.P.; Cerri, C.C. 2009. Crop rotation under no-tillage (in Tibagi, Paraná state, Brazil). I. Soil carbon sequestration. Revista Brasileira de Ciência do Solo 33: 1013-102 (in Portuguese, with abstract in English).

Szinwelski, N.; Rosa, C.S.; Solar, R.R.C.; Sperber, C. 2015. Aggregation of cricket activity in response to resource addition increases local diversity. PloS One 10: e0139669. 